\title{
Determinants Of Auditor's Ability To Detect Fraud: Internal And External Factors
}

\author{
Rizkiana Iskandar ${ }^{1}$, Muh. Syahru Ramadhan ${ }^{2 *}$, M. Ikhwan Mansyuri ${ }^{3}$, Rizky \\ Ramadhan $^{4}$ \\ 1,2,3,4 Department of Accounting, STIE Yapis Dompu, Dompu \\ Nusa Tenggara Barat, 84213, Indonesia. \\ ${ }^{*}$ Corresponding Author: \\ Email: syahru260113@gmail.com
}

\begin{abstract}
.
Fraud cases that occur in Indonesia have fluctuated every year and in 2020 the number of state losses due to fraud is the largest in the last five years. The purpose of this study was to determine the effect of internal factors (experience and professional skepticism) and external (whistleblowing and time budget pressure) on the ability of auditors to detect fraud. Sampling using a survey method in the form of a questionnaire given to respondents, namely internal auditors the inspectorate and produced as many as 55 samples. Data testing was carried out by multiple regression testing using the SPSS version 23 program. The results showed that internal factors consisting of experience and professional skepticism and external factors, namely whistleblowing, had a positive effect on the ability of auditors to detect fraud. Meanwhile, time budget pressure does not prove to have an effect on auditors' ability to detect fraud.
\end{abstract}

Keywords: Fraud detection, audit experience, professional skepticism, whistleblowing, time budget pressure

\section{INTRODUCTION}

Financial statements are one of the aspects used by stakeholders consisting of many constituents including the public and the government in assessing company performance [1]. According to [2] assume a financial audit report is that the report will be used by various parties for various purposes. However, the financial statements themselves are usually vulnerable to material misstatement and security issues. The Association of Certified Fraud Examiners (ACFE) defines fraud as acts that are against the law and carried out with a specific purpose such as providing false reports to other parties. Fraudulent acts carried out by people from inside or outside the organization for personal or group gain that directly or indirectly harm other parties [3].Fraud acts that occur in Indonesia continue to fluctuate from year to year. According to data from Indonesia Corruption Watch [4] regarding the trend of cracking down on corruption cases in the period 2016 to semester 12020 , the total number of corruption cases was 210 consecutive cases in 2016, 266 cases in 2017, 139 cases in 2018, 122 cases in 2017. 2019, and 169 cases in mid-2020. Of all these cases, ICW stated that the value of state losses reached Rp. 28.8 trillion, with the largest state losses in 2020 of Rp. 18.1 trillion. 
Meanwhile, the Corruption Perception Index [5] data shows that in 2020 the country of Indonesia is in the 102 nd position out of 180 countries with a score of 37 on a scale of 0-100 ( 0 means very corrupt and 100 means very clean).For example, one of the fraud cases that occurred in Indonesia was the case of PT. Jiwasraya Insurance. According to a report by the Financial Audit Agency (BPK), Jiwasraya reported false company profits since 2006 due to accounting engineering (window dressing). Jiwasraya failed to pay the JS Saving Plan insurance policy due to a long-standing fraud. In fact, most SOEs have used international public accountants (Big Four) such as EY, PwC, Delloite, and KPMG. Some of the public accountants also had time to stumble in cases of wrong audits and cases of default. Considering the magnitude of the losses caused by the fraud case, the prevention and detection of fraud is important. An auditor should be more careful and thorough when carrying out an audit of financial statements, because if there are problems in detecting fraud, it will have an impact on audit failure [6].

The ability to detect fraud is a manifestation of the quality of an auditor's self. However, the limitations of the auditor to detect fraud can be caused by internal factors (within the auditor) or external factors. Internal factors are closely related to the technical competence of the auditor, which is influenced by how long the auditor is experienced in conducting auditing practices. Experience is one of the requirements that must be met by public accountants to get permission from the minister of finance [2]. Experience in auditing practice owned by an auditor will help increase knowledge about errors and fraud [7, 8, 9,10]. In addition to being experienced, an auditor must also have high professional skepticism to be able to detect fraud [11]. Skepticism is a fundamental and important basis in carrying out SAS (Statement of Auditing Standards) audits No. 1 "Procedure Preparation and Auditing Standards" explains that auditors should apply professional skepticism in considering audits with a questioning mind as well as being critical and objective in analyzing audit evidence and client statements.

Auditors who have a high level of skepticism will more easily detect fraud because of their thorough nature and always looking for the truth of the evidence he received $[8,12,13]$. Meanwhile, acts of fraud in an agency can be identified by the existence of whistleblowing which is used to improve internal control. Whistleblowing is the disclosure of acts of violation or disclosure of unlawful acts and unethical/immoral acts that can harm the organization and stakeholders, which are carried out by employees or organizational leaders to organizational leaders or other institutions that can take action on these violations in secret [14]. The existence of external factors in the form of a whistleblowing system will make the company tend to the principle of openness so that it can assist auditors in detecting fraudulent behavior [13] and [15].The audit practice carried out by the auditor to check whether there are errors or fraud in the financial statements is always demanded in accordance with the stipulated time budget [11]. 
Time budget pressure faced by auditors can cause high levels of stress and affect the attitudes, intentions, and behavior of auditors [16]. If it turns out that the time planned for the audit process does not match the actual time required, then there will be a possibility that an auditor will ignore small things that are considered unimportant for time efficiency. The existence of time restrictions will also make the auditor tend to trust the auditee's information and statements, because they work under strict and rigid time pressure [6]. This shows that auditors who are in a time budget pressure situation will be less sensitive to signs of fraud, so they are less likely to be able to detect fraud.Based on this background description, this research will focus on internal and external factors that affect the auditor's ability to detect fraud. The aim is to find out how an auditor can detect fraud in financial statements with his experience and professional skepticism, as well as the existence of a whistleblowing system even though the time budget pressure is so limited.

\section{THEORETICAL STUDY AND HYPOTHESES DEVELOPMENT Fraud and Fraud Hexagon}

According to the Financial Supervisory Agency, fraud is one type of unlawful act that is carried out intentionally to obtain something by deceiving [17]. Fraud is more emphasized on deviant behavior activities related to legal consequences, such as embezzlement, theft by deception, fraudulent financial reporting, and corruption. At first, someone's actions when committing fraud were based on the Fraud Triangle theory [18] which consists of pressure, rationalization, and opportunity. Over time, it developed into a Fraud Diamond with an additional capability factor [19]. Furthermore, [20] also introduced the development of the Fraud Triangle theory, namely the Pentagon Fraud with 2 additional points, namely competence and arrogance. The last development of the fraud theory is the Fraud Hexagon formulated by [21] with the addition of the collucion factor.

The Fraud Hexagon theory that can encourage fraud consists of 1) pressure, which is a condition of stimulated pressure when the company's performance is at a point below the average industry performance, 2) Capability, which shows how much power and the capacity of someone who commits fraud in the company environment, 3) Opportunity, things that begin to appear when there is a weakness in the company's internal control system. 4) rationalization, is a justification that arises in management's mind when fraud has occurred, 5) arrogance (ego), is an attitude of superiority or greed from people who believe that internal control does not apply personally [22]. The last factor is, 6) collucion (collusion) which refers to the existence of a deceptive agreement or between two or more people, for one party to take another action for some unfavorable purpose, such as to deceive third parties from their rights [21]. Detection of fraud by the auditor is a process of identifying various indicators of fraud so that the auditor can decide whether to test or not [23]. Fraud detection as an early 
detection effort must be carried out so that fraudulent actions can be prevented from being carried out and to determine whether or not testing is necessary [15].

\section{Audit Experience and Auditor Ability to Detect Fraud}

Audit experience is a factor that can only be developed by an auditor through the number of assignments carried out so that it can affect the auditor's ability to detect fraud [8]. Furthermore, auditors with high experience will have more effective methods or techniques found based on experience when conducting audits [15]. [6] states that an experienced auditor is an auditor who is able to detect, understand and look for the causes of the emergence of fraud. According to [2] an auditor who applies for permission to become a public accountant from the Minister of Finance must have experience in the field of general auditing on financial statements for at least 1000 hours of assignments in the last 5 years.

Therefore, auditors with more experience in auditing practices will find it easier to obtain quality audit evidence to reveal fraud when compared to auditors with less experience, which of course will be more difficult to obtain evidence in disclosing fraud.Research conducted by [8] shows that experienced auditors can detect fraud better. This is supported by $[7,12,11]$ that auditor experience has a positive effect on the auditor's ability to detect fraud. In contrast to research [24] and [15] which found evidence of auditor experience will not affect the ability of auditors to detect fraud. Based on this description and the differences in the results of previous studies, the first hypothesis can be formulated as follows:

\section{H1: The experience of the auditor has a positive effect on the ability of the auditor to detect fraud.}

\section{Professional Skepticism and Auditor Ability to Detect Fraud}

Auditor professional skepticism is needed to produce reliable financial reports. Professional skepticism is an attitude that always questions something in the mind, is alert to any conditions that indicate a possible misstatement due to error or fraud, as well as a critical assessment of evidence [25]. High skepticism in an auditor will increase the ability to detect fraud by developing a search for various additional related information when faced with symptoms of fraud [7].

Therefore, auditors who have a high level of skepticism can more easily detect fraud because they are more thorough, always seek the truth, and conduct critical evaluations of audit evidence. The higher the attitude of professional skepticism, the smaller the possibility of undetected fraud.The results of the research $[12,13,26,8]$ found a positive influence between the auditor's skepticism and the ability to detect fraud. [11] Arsendy et al., (2017) also revealed that auditors who have high professional skepticism will be better able to detect fraud. Meanwhile, research [7] shows that there is no relationship between professional skepticism and the ability of auditors to detect fraud. Based on this description and the differences in the results of previous studies, the second hypothesis can be formulated as follows: 


\section{H2: Professional skepticism has a positive effect on the auditor's ability to detect fraud.}

\section{Whistleblowing and Auditor Ability to Detect Fraud}

The ethical values that serve as the basis for the existence of whistleblowing are the values of honesty, openness, protection of the public interest and rejection of deviations from rules and professions [26]. According to [27] how big and serious a fraud act that has the potential to harm an institution or company will encourage someone to take whistleblowing actions. The whistleblowing system was created with the aim of monitoring internal violations within the institution or company, as a form of effort so that anyone can report crimes that occur to prevent losses that will be suffered by the company, which is adjusted to company rules [15].

The existence of a whistleblowing system will assist the auditor in detecting any fraudulent behavior that occurs. This means that the more reports that come in from the whistleblowing system, the more information and additional evidence the auditor gets to detect the fraud.The results of the study [13] provide evidence that the whistleblowing system has a positive effect on the auditor's ability to detect fraud. This is reinforced by [15] who found that whistleblowing can help auditors make the time to find evidence of violations faster. In addition, research conducted by [28] shows that the whistleblowing system has a significant positive effect on fraud prevention. Based on this description, the third hypothesis can be formulated as follows:

\section{H3: Whistleblowing has a positive effect on the auditor's ability to detect fraud. \\ Time Budget Pressure and Auditor Ability to Detect Fraud}

Time budget pressure is a factor that comes from outside the auditor's self which is considered to be able to determine and affect the auditor's ability to detect fraud. According to [29] time budget pressure is a situation related to auditors who perform time efficiency audits that have been prepared before the assignment. In addition, there are very strict and rigid time and budget restrictions. Time budget pressure conditions faced by auditors in carrying out audit practices can affect the attitudes, intentions, and behavior of auditors due to high stress levels [30].

According [6], the existence of time pressure will make the auditor have a busy period because he adjusts the tasks that must be completed with the available time. Therefore, auditors who are in time budget pressure situations are usually not careful and less sensitive to symptoms of fraud and tend to ignore small things that are considered unimportant so that the ability to detect fraud is not used optimally.Research $[11,6]$ reveal that time pressure has a negative effect on the auditor's ability to detect fraud. This is in line with research [11] which found that an auditor who has time budget pressure will be less able to detect fraud. Meanwhile, research [30] shows that there is no relationship between time budget pressure and the auditor's ability to detect fraud. Based on this description and the differences in the results of previous studies, the fourth hypothesis can be formulated as follows: 


\section{H4: Time budget pressure negatively affects the auditor's ability to detect fraud.} Research Framework

Based on the theoretical basis and previous research, the research framework is structured as follows.

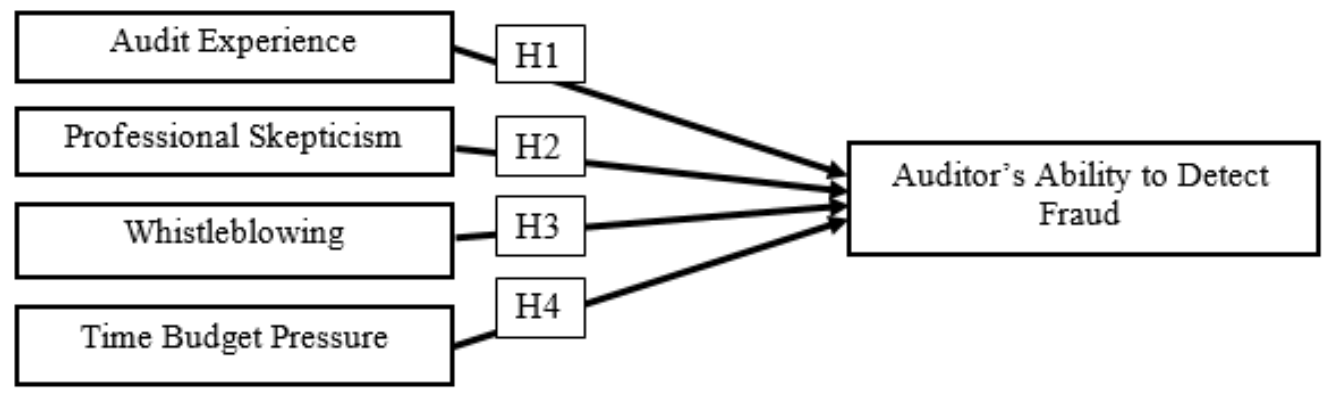

Fig 1. Research Framework

\section{METHODS}

\section{Population, Sample, and Data Collection Method}

This study took respondents from all auditors who worked at the Inspectorate of Dompu Regency, amounting to 55 respondents. Furthermore, the sampling method used purposive sampling, namely sampling on certain aspects. The criteria used are auditors who work at the Dompu Regency Inspectorate Office, auditors who have one year of experience. The research data was collected using a survey method using a questionnaire. Questionnaires are distributed by giving a set of questions or written statements to respondents to answer. The questionnaire distributed consists of 6 parts. The first part includes the respondent's identity and is followed by the second to sixth parts which contain questions related to the research variables instruments.The first stage of data analysis technique is the discussion of the demographics of the respondents.

In addition, the measurement of data quality is verified with validity and reliability tests, each of which is used to measure the validity of the questionnaire and to test an indicator of a variable or construct. Furthermore, the classical assumption test is carried out which includes: a) Data normality test, which is used to determine a regression model consisting of the dependent variable and the independent variable being normally distributed or not. The regression model should have data that are normally distributed or at least close to normal, b) multicollinearity test, where there is no or no linear correlation between two or more independent variables, c) heteroscedasticity test, which is a test carried out to find out whether in a regression model there is residual variance that is not the same from one observation to another [31]. While the multiple regression test is used as an analytical model to determine the effect of the independent variable on the dependent variable. These variables are experience, professional skepticism, whistleblowing, time budgeted pressure, on fraud detection. Based on this explanation, the linear regression model is as follows: 


$$
\mathrm{DF}_{i t}=\boldsymbol{\alpha}_{0}+\boldsymbol{\beta}_{1} \mathrm{PA}_{i t}+\boldsymbol{\beta}_{2} \mathrm{SP}_{i t}+\boldsymbol{\beta}_{3} \mathrm{WB}_{i t}+\boldsymbol{\beta}_{4} \mathrm{TBP}_{i t}+\varepsilon_{i t}
$$

Description:

DFit $\quad=$ Fraud Detection Variable

PAit = Audit Experience Variable

SPit $=$ Professional Skepticism Variable

WBit $=$ Whistleblowing Variable

TBPit $=$ Variable Time Budget Pressure

$\mathbf{s}_{\boldsymbol{t} t} \quad=$ error

\section{RESULT AND DISCUSSION}

Descriptive Statistical Test. The purpose of this test is to obtain an overview of the research data, including the minimum, maximum, mean, and standard deviation of the data. Based on the data in Table 1 regarding the results of descriptive statistical tests, each independent variable is fraud detection, and the dependent variable consists of four variables, experience, professional skepticism, whistleblowing and time budgeted pressure. The minimum value of the five research variables shows a range of values between 3.00 to 3.50 which means that the lowest answer of the respondent is focused on the opinion of "slightly disagree" with the statement in the questionnaire.

Meanwhile, the maximum value of all variables is 6.00 or is in the "strongly agree" answer on the questionnaire statement item. Furthermore, the average value of all variables is at a value of more than 5, which indicates that on average all respondents' answers choose "agree" to the statement submitted. This is in accordance with the test results which reveal that all independent variables can affect fraud detection. The results of statistical tests also reveal that the standard deviation value is higher than the average value, which means that the research data has a high degree of variation.

Table 1. Descriptive Statistical Test Results

\begin{tabular}{|c|c|c|c|c|}
\hline Variable & Minimum & Maximum & Mean & Standard Deviatiol \\
\hline Audit Experience & 3,00 & 6 & 5,20 & 7.42 \\
\hline Professional Skepticism & 3,50 & 6 & 5.12 & 5.83 \\
\hline Whistleblowing & 4,22 & 6 & 5.21 & 6.62 \\
\hline Time Budget Pressure & 3,00 & 6 & 5.18 & 7.05 \\
\hline Fraud Detection & 3,38 & 6 & 5.11 & 5.63 \\
\hline
\end{tabular}

Source: Data processed, 2021

\section{Classical Assumptions and Data Quality Testing}

Based on the results of data quality testing, all statement items that measure the auditor's ability to detect fraud, audit experience, professional skepticism, 
whistleblowing, and time budget pressure are declared valid. This happens because all statement items produce a correlation value $>\mathrm{r}$ table of 0.261 as shown in Table 2 .

Table 2. Validity Test Results

\begin{tabular}{|c|c|c|c|c|}
\hline Variable & $\begin{array}{c}\text { Statement } \\
\text { Items }\end{array}$ & $\begin{array}{c}\text { Pearson } \\
\text { Correlation } \\
\end{array}$ & $\begin{array}{c}\mathrm{r}- \\
\text { table }\end{array}$ & Decision \\
\hline \multirow{8}{*}{$\begin{array}{l}\text { Auditor's ability to detect } \\
\text { fraud }\end{array}$} & Y1.1 & $0,768 * *$ & 0,261 & Valid \\
\hline & Y1.2 & $0,751 * *$ & 0,261 & Valid \\
\hline & Y1.3 & $0,830 * *$ & 0,261 & Valid \\
\hline & Y1.4 & $0,783 * *$ & 0,261 & Valid \\
\hline & Y1.5 & $0,796 * *$ & 0,261 & Valid \\
\hline & Y1.6 & $0,774 * *$ & 0,261 & Valid \\
\hline & Y1.7 & $0,760 * *$ & 0,261 & Valid \\
\hline & Y1.8 & $0,691 * *$ & 0,261 & Valid \\
\hline \multirow{6}{*}{ Audit Experience } & $\mathrm{X} 1.1$ & $0,887 * *$ & 0,261 & Valid \\
\hline & $\mathrm{X} 1.2$ & $0,893 * *$ & 0,261 & Valid \\
\hline & $\mathrm{X} 1.3$ & $0,910 * *$ & 0,261 & Valid \\
\hline & $\mathrm{X} 1.4$ & $0,877 * *$ & 0,261 & Valid \\
\hline & $\mathrm{X} 1.5$ & $0,874 * *$ & 0,261 & Valid \\
\hline & $\mathrm{X} 1.6$ & $0,895 * *$ & 0,261 & Valid \\
\hline \multirow{6}{*}{ Professional Skepticism } & $\mathrm{X} 2.1$ & $0,809 * *$ & 0,261 & Valid \\
\hline & $\mathrm{X} 2.2$ & $0,862 * *$ & 0,261 & Valid \\
\hline & $\mathrm{X} 2.3$ & $0,852 * *$ & 0,261 & Valid \\
\hline & $\mathrm{X} 2.4$ & $0,872 * *$ & 0,261 & Valid \\
\hline & $\mathrm{X} 2.5$ & $0,769 * *$ & 0,261 & Valid \\
\hline & $\mathrm{X} 2.6$ & $0,595 * *$ & 0,261 & Valid \\
\hline \multirow{9}{*}{ Whistleblowing } & $\mathrm{X} 3.1$ & $0,898 * *$ & 0,261 & Valid \\
\hline & $\mathrm{X} 3.2$ & $0,879 * *$ & 0,261 & Valid \\
\hline & $\mathrm{X} 3.3$ & $0,913 * *$ & 0,261 & Valid \\
\hline & X3.4 & $0,905 * *$ & 0,261 & Valid \\
\hline & $\mathrm{X} 3.5$ & $0,870 * *$ & 0,261 & Valid \\
\hline & X3.6 & $0,882 * *$ & 0,261 & Valid \\
\hline & $\mathrm{X} 3.7$ & $0,776 * *$ & 0,261 & Valid \\
\hline & $\mathrm{X} 3.8$ & $0,770 * *$ & 0,261 & Valid \\
\hline & X3.9 & $0,774 * *$ & 0,261 & Valid \\
\hline \multirow{6}{*}{ Time Budget Pressure } & $\mathrm{X} 4.1$ & $0,841 * *$ & 0,261 & Valid \\
\hline & $\mathrm{X} 4.2$ & $0,844 * *$ & 0,261 & Valid \\
\hline & $\mathrm{X} 4.3$ & $0,866 * *$ & 0,261 & Valid \\
\hline & $\mathrm{X} 4.4$ & $0,873 * *$ & 0,261 & Valid \\
\hline & $\mathrm{X} 4.5$ & $0,866 * *$ & 0,261 & Valid \\
\hline & $X 4.6$ & $0,788 * *$ & 0,261 & Valid \\
\hline
\end{tabular}

Source: Data processed, 2021

Furthermore, testing the reliability of the data shows that the statement in the questionnaire has a Cronbach's alpha value greater than 0.6 which means the data is reliable. The summary of the reliability test results is shown in Table 3.

Table 3. Reliability Test Results 


\begin{tabular}{lllll}
\hline Auditor's ability to detect fraud & 8 & 0,927 & 0,60 & Reliable \\
Audit Experience & 6 & 0,947 & 0,60 & Reliable \\
Professional Skepticism & 6 & 0,880 & 0,60 & Reliable \\
Whistleblowing & 9 & 0,953 & 0,60 & Reliable \\
Time Budget Pressure & 6 & 0,919 & 0,60 & Reliable \\
\hline
\end{tabular}

Source: Data processed, 2021

After conducting the data quality test, the next test is the classical assumption test which includes the normality test, heteroscedasticity test, and multicollinearity test. The summary of the results of the normality test of the data is contained in Table 4. The results of the Kolmogorov-Smirnov test indicate that the data in the regression model in this study are normally distributed because the significance value is 0.829 ( $>$ $0.05)$.

Table 4. Data Normality Test Results

\section{Unstandardized Residual} Model Regresi

\section{Decision}

\begin{tabular}{lcc}
\hline $\mathrm{n}$ & 55 & \\
Kolmogorov-Smirnov Z & 0,625 & Normal Distributed Data \\
Asymp. Sig. (2-tailed) & 0,829 & \\
\hline
\end{tabular}

Source: Data processed, 2021

Meanwhile, based on the results of heteroscedasticity testing, the significance value of all independent variables in this study is more than 0.05 , which means that the regression model meets the assumption of heteroscedasticity or the regression model has homogeneous data variations. Table 5 below shows a summary of the results of the heteroscedasticity test.

Table 5. Heteroscedasticity Test Results

\begin{tabular}{lllll}
\hline \multicolumn{1}{c}{ Model } & t & Sig. & Decision \\
\hline (Constant) & & & \\
Audit Experience & 0,040 & 0,004 & \\
\multirow{2}{*}{$1 \quad$ Professional Skepticism } & $-0,722$ & 0,474 & Heteroscedasticity does not occur \\
& Whistleblowing & $-1,440$ & 0,159 & Heteroscedasticity does not occur \\
Time Budget Pressure & $-0,575$ & 0,566 & Heteroscedasticity does not occur
\end{tabular}

Source: Data processed, 2021

Furthermore, the results of the multicollinearity test in Table 6 show the VIF value of each independent variable is less than 10 and the tolerance value is more than 0.10 . Therefore, it is certain that there is no multicollinearity problem between the independent variables in this study. 
Table 6. Multicollinearity Test Results

\begin{tabular}{lccl}
\hline \multicolumn{1}{c}{ Variable } & \multicolumn{2}{c}{ Collinearity Statistics } & Decision \\
& Tolerance & VIF & \\
\hline Audit Experience & 0,674 & 1,484 & Multicollinearity does not occur \\
Professional Skepticism & 0,797 & 1,254 & Multicollinearity does not occur \\
Whistleblowing & 0,739 & 1,354 & Multicollinearity does not occur \\
Time Budget Pressure & 0,893 & 1,120 & Multicollinearity does not occur \\
\hline
\end{tabular}

Source: Data processed, 2021

\section{Hypothesis test}

The regression model was used to examine the effect of the independent variables, namely audit experience, professional skepticism, whistleblowing, and time budget pressure on the auditor's ability to detect fraud. A summary of the test results is shown in Table 7.

Table 7. Regression Model Test Results

\begin{tabular}{|c|c|c|c|c|}
\hline Model & $\begin{array}{c}\text { Unstandardized } \\
\text { B }\end{array}$ & $\begin{array}{l}\text { Coefficients } \\
\text { Std. Error }\end{array}$ & Sig. & Decision \\
\hline (Constant) & 3,050 & 4,883 & $0,6250,535$ & \\
\hline Audit Experience & 0,396 & 0,111 & $3,5830,001$ & Supported hypothesis \\
\hline Professional Skepticism & 0,374 & 0,129 & $2,8890,006$ & Supported hypothesis \\
\hline Whistleblowing & 0,179 & 0,079 & $2,2620,028$ & Supported hypothesis \\
\hline Time Budget Pressure & 0,175 & 0,101 & $1,7340,089 \mathrm{H}$ & ypothesis is not supported \\
\hline Dependent Variable: & \multicolumn{4}{|l|}{ Fraud Detection } \\
\hline $\mathbf{n}$ & \multicolumn{4}{|l|}{55} \\
\hline R Squared & \multicolumn{4}{|l|}{0,582} \\
\hline Adjusted R Squared & \multicolumn{4}{|l|}{0,549} \\
\hline F Statistic & \multicolumn{4}{|l|}{17,430} \\
\hline Prob. (F-Statistic) & \multicolumn{4}{|l|}{0,000} \\
\hline
\end{tabular}

Source: Data processed, 2021

Based on the summary of the results of the regression model test output shown in Table 7, the adjusted R-square value is 0.549 . This means that $54.9 \%$ of the auditor's ability to detect fraud can be explained by variations in the independent variables. Meanwhile, the probability (F-statistic) shows a value of 0.000 (Prob. F-statistic $<0.05$ ). Therefore, the decisions taken are all independent variables together or there is at least one independent variable that has a significant influence on the dependent variable. Furthermore, hypothesis 1 (H1) is stated to be supported because the experience variable coefficient is positive (0.001) and significant at the 5\% level, which means that experience has an effect on fraud detection. Hypothesis 2 and hypothesis 3, each with a coefficient value of 0.006 and 0.028 and a significance $<0.05$, proves that professional skepticism and whistleblowing have a positive effect on 
fraud detection. Meanwhile, hypothesis 4 is not supported because the significance value is $0.089>0.05$. This means that there is no effect of time budget pressure on fraud detection by auditors.

\section{Discussion}

\section{Auditor experience and auditor's ability to detect fraud.}

Testing the first hypothesis (H1) provides empirical evidence that there is a positive influence between audit experience and the auditor's ability to detect fraud. Auditors also often attend a lot of training and perform tasks that ensure audit quality. As required in [32], an auditor is required to have education, mastery of duties, abilities, skills, experience, and other abilities needed to account for the auditor's duties, so that the auditor can optimally fulfill his professional auditor responsibilities. So auditors are encouraged to demonstrate their auditing abilities in view of the results of professional exams or auditor certifications such as the Certified Internal Auditor (CIA) [33]. Not only that, with many assignments that are often carried out by the auditor, it will affect the decisions made and the auditor can analyze problems and assist the auditor in predicting and detecting problems, so as to increase professionalism in work. There are two main aspects that shape the ability or competence of an auditor, namely experience and knowledge [34].

The more experienced the auditor, the better the ability to address any audit problems that may arise during the audit. This means that experience is an important factor in detecting fraud. The experience of an auditor is obtained through the number of assignments or audit practices carried out, as well as how long he has been in the profession as an auditor so that skills become honed over time. Auditors who have high work experience tend to be better at carrying out various activities such as detecting errors, understanding errors and finding faults. If we relate it to the implementation of audits, it is not surprising that experienced auditors assigned to conduct fraud audits tend to be better at detecting fraud. This is because experienced auditors sometimes have a more effective method because this method can be found based on the experience of an auditor in the field. [35] revealed that the auditor's experience will be further developed by conducting discussions about auditing with colleagues, supervision and review by senior accountants, participating in training programs and using auditing standards.

This is able to make the auditor more sensitive and able to see any irregularities that might lead to fraud [6]. This is supported by [7], that experienced auditors will also have a better understanding of the causes of errors that occur, whether purely human errors that are unintentional or intentional errors which mean fraud. Auditors will always question and evaluate critically the evidence they get so that they can detect fraud. Meanwhile, if the auditors do not have sufficient experience in the field of auditing, do not have many assignments, or are even new to the world of auditing, they will have difficulty finding irregularities or indications of fraud in the 
financial statements presented and in the audit evidence obtained. The results of this study are in line with research conducted by $[12,36,11]$ that auditor experience has a positive effect on the auditor's ability to detect fraud. With the findings of this study, the implication for the inspectorate is to increase the experience and knowledge of auditors through audit assignments, workshops, training and special audit certification exams so that the auditor's ability to increase so that they can detect fraud.

Professional skepticism and the ability of auditors to detect fraud. Testing the second hypothesis (H2) shows evidence that there is an effect of professional skepticism on the auditor's ability to detect fraud. The coefficient value with a positive number indicates that there is a positive influence which indicates the higher the level of professional skepticism of the auditor, the better the auditor's ability to detect fraud will be. Auditors are proven to be able to make critical assessments and question the reliability of the audit evidence or assertions obtained so that they try to find valid evidence that supports these assertions.

In addition, professional skepticism is also shown in the implementation of audit practices, namely the auditor always provides responses and questions from information submitted by management and related parties. In achieving the expected goals and results, the auditor must carry out his duties with skill and apply the knowledge he has learned during his work in making judgments and conclusions by using an attitude of skepticism to be able to detect fraud. The results of this study are in line with $[12,13]$ which found a positive influence between the auditor's skepticism and his ability to detect fraud. [11] also revealed that auditors who have high professional skepticism will be better able to detect fraud. This finding confirms the attribution theory that a person's attitude or action is strongly influenced by his or her internal factors [8].

\section{Whistleblowing system and auditor's ability to detect fraud.}

Furthermore, the results of testing hypothesis 3 prove that the whistleblowing system has a positive effect on the auditor's ability to detect fraud. Wistleblowing is the act of an informant who reveals fraud in an organization with the aim of stopping fraudulent actions. Auditors benefit from the existence of a whistleblowing system whose sources of information come from internal and external parties. Thus, it can be seen that the more information obtained from whistleblowing, the more the auditor will be assisted in the fraud detection process. This is because the whistleblowing system in an agency or company can play an important role in increasing the effectiveness of the auditor's examination because it is easier to explore the potential for fraud committed by the auditee (client or party being audited). In this case, the auditor will receive, review, and follow up on incoming information through whistleblowing so as to reduce the risk of fraud being detected. The results of this study support previous research conducted by $[13,15]$ which found that whistleblowing can help auditors make the time to search for evidence of violations faster, making it easier to uncover cases of 
fraud.[37] revealed that the existence of a whistleblowing system that runs optimally can create fear for employees to commit fraud.

This is because there have been many fraud reporting systems that are owned by every government agency and are very easily accessible by all parties. Therefore, with the existence of whistleblowing, it is expected to be able to encourage the government or all related parties to take advantage of the whistleblowing system to report fraudulent acts that occur, so that fraud prevention efforts in government financial management can run optimally. The whistleblowing system is very effective in preventing fraud by requiring the government's commitment to protect the whistleblower's personal data, a clear and responsible reporting mechanism and system improvement [38]. By implementing whistleblowing within the government, the government will be able to effectively prevent and detect fraud, so that government assets are protected from misuse by irresponsible people. The results of this study are in line with [39] revealing that the presence of whistleblowing in the organization will reveal all forms of fraudulent acts. Furthermore, [40] revealed that the implementation of whistleblowing in the government is an effective strategy to prevent fraudulent acts, so that fraud perpetrators will think twice about committing fraud.

Time budget pressure and auditor's ability to detect fraud. In contrast to the results of the other three hypotheses, hypothesis 4 cannot be supported, which means that time budget pressure does not affect the auditor's ability to detect fraud. The results of this study are in line with the findings [16] which show that there is no relationship between time budget pressure and the auditor's ability to detect fraud. However, this is in contrast to several previous studies conducted by $[8,11,6]$. Thus, the time budget pressure does not affect the success or failure of the auditor in detecting fraud because the auditor has been given a time budget that is in accordance with the scope of the audit assigned to him.According to research by [6], the time pressure faced by the auditor will be responded to in two ways, namely functional and dysfunctional.

The functional type leads to the behavior of auditors who actually work better and use the time as much as possible so that the audit quality can be maintained. Meanwhile, the dysfunctional type is the auditor's behavior that causes a decrease in audit quality because the auditor prioritizes tasks so that they are more likely to miss audit evidence that leads to fraud cues. The results of this study indicate that auditors are more inclined to the functional type. Thus, the results of this study have implications for how the inspectorate prepares its auditors to be able to deal with time budget pressure when carrying out assignments the auditor will use his ability to detect irregularities. So that the relevant guidelines before carrying out an audit assignment will greatly assist the process of carrying out the audit examination, so that the auditor can detect fraud. 


\section{CONCLUSION, LIMITATIONS, AND SUGGESTIONS Conclusion}

This study aims to examine the effect of internal (experience and professional skepticism) and external (whistleblowing and time budget pressure) factors on the auditor's ability to detect fraud. Based on the results of testing the data, it can be concluded that the auditor's experience has a positive effect on the auditor's ability to detect fraud. That is, the more work experience an auditor has, the better the auditor's ability to detect fraud will be. Furthermore, professional skepticism has a positive effect on the auditor's ability to detect fraud. This indicates that the higher the level of professional skepticism of the auditor, the better the auditor's ability to detect fraud will be. Whistleblowing has a positive effect on the auditor's ability to detect fraud. This means that the information obtained from the whistleblowing system will make it easier for the auditor to find fraud that has occurred. Then, time budget pressure does not have a negative effect on the auditor's ability to detect fraud. This shows that auditors tend to be functional types that actually work better and can maximize time so that audit quality can be maintained even under pressure.

\section{Limitations and Suggestions}

This study has several limitations that may affect the research results achieved. The following are limitations in this study. The distribution of the questionnaires was carried out at times that were quite busy for the respondents. So this is a bit of an obstacle in the process of filling out the questionnaire. Based on the limitations experienced by the researcher, it is better for further research to distribute questionnaires when the respondents are not in busy periods, so that the number of respondents becomes more and can expand the scope of the research sample so that the research results can be generalized more broadly. In addition, there are many other external and internal factors that might affect the auditor's ability to detect fraud, so that it can be tested for future research.

\section{REFERENCES}

[1] Freeman, R. E., \& Reed, D. L. (1983). Stockholders and Stakeholdes: A New Perpective on Corporate Governance. California Management Review, 27(3), 88. https://doi.org/10.5897/ajmr2014.7057.

[2] Jusup, A. H. (2014). Auditing (Pengauditan Berbasis ISA) (2nd ed.). Sekolah Tinggi Ilmu Ekonomi YKPN.

[3] ACFE.Inc. (2020). Report To the Nations 2020 Global Study on Occupational Fraud and Abuse. Association of Certified Fraud Examiner,Inc.

[4] ICW. (2020). Laporan Pemantauan Tren Penindakan Kasus Korupsi Semester I 2020. In Indonesia Corruption Watch.

[5] CPI. (2020). Corruption Perceptions Index.

[6] Anggriawan, E. F. (2014). Pengaruh Pengalaman Kerja, Skeptisisme Profesional, dan Tekanan Waktu Terhadap Kemampuan Mendeteksi Fraud (Studi Empiris pada Kantor Akuntan Publik di DIY). Jurnal Nominal, 3(2), 101-116. 
[7] Suryanto, R., Indriyani, Y., \& Sofyani, H. (2017). Determinan Kemampuan Auditor dalam Mendeteksi Kecurangan. Jurnal Akuntansi Dan Investasi, 18(1), 102-118. https://doi.org/10.18196/jai.18163.

[8] Indriyani, S., \& Hakim, L. (2021). Pengaruh Pengalaman Audit, Skeptisme Profesional dan Time Pressure Terhadap Kemampuan Auditor Mendeteksi Fraud. Jurnal Akuntansi Dan Governance, 1(1), 113-120.

[9] Jannah, F., \& Pratono, R. (2021). Pengaruh Gender, Tipe Kepribadian , Tingkat Pendidikan, dan Pengalaman Audit Terhadap Skeptisme Auditor Internal Pemerintah (Studi Empiris pada Inspektorat Provinsi Jawa Timur). Economie, 2(2), 158-177.

[10] Firtiana, A. V. (2019). Faktor Internal Auditor yang Mempengaruhi Kemampuan Auditor dalam Mendeteksi Kecurangan. Jurnal Online Insan Akuntan, 4(2), 2. https://doi.org/10.25105/semnas.v0i0.5847.

[11] Arsendy, M. T., Anugerah, R., \& Diyanto, V. (2017). Pengaruh Pengalaman Audit, Skeptisme Profesional, Reg Flags, Dan Tekanan Anggaran Waktu Terhadap Kemampuan Auditor Dalam Mendeteksi Kecurangan (Studi Empiris Pada KAP Di DKI Jakarta). JOM Fekom, 4(1), 1096-1107.

[12] Arfiana. (2019). Pengaruh Pengalaman Kerja, Religiusitas, dan Skeptisme Profesional terhadap Kemampuasn Auditor Internal dalam Mendeteksi Kecurangan (Studi pada Kantor Inspektorat Kabupaten Buton Tengah dan Kabupaten Buton Selatan). Jurnal Akademik Pendidikan Ekonomi, VI(1), 99-106.

[13] Permana, Y., \& Eftarina, M. (2020). Peran Whistleblowing System dalam Memoderasi Pengaruh Skeptisme Profesional Terhadap Kemampuan Auditor dalam Mendeteksi Kecurangan. Prosiding Seminar Nasional Pakar Ke 3 Tahun 2020 Buku 2: Sosial Dan Humaniora, 3(2), 2.14.1-1.14.6.

[14] KNKG. (2008). Menggagas Sistem Whistleblower di Indonesia. Whistle Blower System Proceedings, 2, 1-11.

[15] Rahmida, M., \& Urumsah, D. (2020). Determinan deteksi fraud audit: peran moderasi gender dan pengalaman. Proceeding of National Conference on Accounting \& Finance, 2, 1-10. https://doi.org/10.20885/ncaf.vol2.art1.

[16] Pangestika, W., Taufik, T., \& Silfi, A. (2014). Pengaruh Keahlian Profesional, Independensi, dan Tekanan Anggaran Waktu Terhadap Pendeteksian Kecurangan (Studi Empiris pada Bada Pemeriksa Keuangan Perwakilan Provinsi Riau). Jom Fekom, 1(2), $1-15$.

[17] BPK. (2017). Ikhtisar Hasil Pemeriksaan Semester 1 Tahun 2017.

[18] Gartner, I. R., Administração, P., Pesquisa, F., \& Fernuni, O. (2017). Triângulo de fraudes de Cressey ( 1953 ) e teoria da agência: estudo aplicado a instituições bancárias brasileiras. 108-140.

[19] Wolfe, D. T., \& Hermanson, D. R. (2004). The Fraud Diamond: Considering the Four Element of Fraud. The CPA Journal, 74(12), 38-42.

[20] Marks, J. (2012). The Mind Behind The Fraudsters Crime: Key Behavioral and Environmental Elements Discussion Leader: Crowe Howard, LPP (Presentation)., 162.

[21] Vousinas, G. (2019). Elaborating on the Theory of Fraud. New Theoretical Extensions. Journal of Financial Crime,

http://ijstm.inarah.co.id 
26(1), 372-381. https://doi.org/10.2139/ssrn.3163337.

[22] Sari, S. P., \& Nugroho, N. K. (2020). Financial Statements Fraud dengan Pendekatan Vousinas Fraud Hexagon Model: Tinjauan pada Perusahaan Terbuka di Indonesia. 1st Annual Conference of Ihtifaz: Islamic Economics, Finance, and Banking, 409-430. http://seminar.uad.ac.id/index.php/ihtifaz/article/download/3641/1023.

[23] BPKP. (2008). Pelaksanaan Raker Pusdiklatwas BPKP tahun 2008. Pusdiklatwas BPKP. https://pusdiklatwas.bpkp.go.id/konten/show/71.

[24] Larasati, D., Andreas, \& Rofika. (2020). Teknik Audit Investigasi, Pengalaman dan Profesionalisme Auditor Pada Pengungkapan Kecurangan: Kecerdasan Spiritual Sebagai Pemoderasi. Jurnal Kajian Akuntansi Dan Bisnis Terkini, 1(1), 150-169.

[25] Tuanakotta, T. M. (2016). Akuntansi Forensik dan Audit Investigatif (2nd ed.). Salemba Empat.

[26] Maulida, W. Y., \& Bayunitri, Bu. I. (2021). The influence of whistleblowing system toward fraud prevention. International Journal of Financial, Accounting, and Management, 2(4), 275-294. https://doi.org/10.35912/ijfam.v2i4.177.

[27] Primasari, R. A., \& Fidiana, F. (2020). Whistleblowing Berdasarkan Intensitas Moral, Komitmen Profesional, dan Tingkat Keseriusan Kecurangan. Jurnal Kajian Akuntansi, 4(1), 63-77. https://doi.org/10.33603/jka.v4i1.3383.

[28] Suastawan, I. M. D. P., Sujana, E., \& Sulindawati, N. luh G. E. (2017). Pengaruh Budaya Organisa, Proactive Fraud Audit, dan Whistleblowing Terhadap Pencegahan Kecurangan dalam Pengelolaan Dana Bos (Studi Empiris pada Sekolah-Sekolah di Kabupaten Buleleng). E-Journal S1 Ak Univ. Pendidikan Ganesha, 1(3), 1-12.

[29] Kirana, I. G. A. M. I., \& Ramantha, I. W. (2020). The effect of auditor rotation, time pressure, and audit tenure on audit quality with auditor specialization as moderation variable (empirical study of manufacturing companies listed on the Indonesia stock exchange in 2014-2018). International Research Journal of Management, IT and Social Sciences,

7(3), 126-136. https://doi.org/10.21744/irjmis.v7n3.931.

[30] Pangestika, W., Taufik, T., \& Silfi, A. (2014). Pengaruh Keahlian Profesional, Independensi, dan Tekanan Anggaran Waktu Terhadap Pendeteksian Kecurangan (Studi Empiris pada Bada Pemeriksa Keuangan Perwakilan Provinsi Riau). Jom Fekom, 1(2), $1-15$.

[31] Ghozali, I. (2016). Aplikasi Analisis Multivariate Dengan Program IBM SPSS 23 (8th ed.). Badan Penerbit Universitas Diponegoro.

[32] Asosiasi Auditor Intern Pemerintah Indonesia (AAIPI). (2014). Indonesian Government Audit Standards. Jakarta.

[33] Asmara, R. Y. (2017). The Effects of Internal Auditors Competence and Independence on Proffesional Judgment: Evidence from Indonesia. International Journal of Economic Perspective, 11(2), 300-308.

[34] Dewi, S. R. K., \& Nurfadila. (2018). Pengaruh Kompetensi Auditor, Profesionalisme, Dan Sistem Pengendalian Internal Terhadap Kualitas Audit. CESJ: Center Of Economic Students Journal,

1(1), 93-107. http://jurnal.fe.umi.ac.id/index.php/CESJ/article/view/143.

[35] Dasila, R. A., \& Hajering, H. (2019). Pengaruh Pengalaman, Independensi Dan Skeptisme Profesional Auditor Terhadap Pendeteksian Fraud. 
Jurnal Ilmu Ekonomi, 2(1), 69-73.

[36] Rahmawati, P., \& Halmawati. (2020). Pengaruh Locus Of Control dan Tekanan Anggaran Waktu terhadap Perilaku Disfungsional Auditor: Studi Empiris pada Kantor Akuntan Publik di Kota Padang. Wahana Riset Akuntansi, 8(1), 35. https://doi.org/10.24036/wra.v8i1.109102.

[37] Wakhidah, A. K., \& Mutmainah, K. (2021). Bystander Effect, Whistleblowing System , Internal Locus Of Control dan Kompetensi Aparatur dalam Pencegahan Fraud Dana Desa. Journal of Economic, Business and Engineering (JEBE), 3(1), 29-39.

[38] Marciano, B., Syam, A., Suyanto, \& Ahmar, N. (2021). Whistleblowing System dan Pencegahan Fraud: Sebuah Tinjauan Literatur. Jurnal Akuntansi Berkelanjutan Indonesia, 4(3), 313-324. https://doi.org/http://dx.doi.org/10.32493/JABI.v4i3.y2021.p313-324.

[39] Nurul, R., \& Herliansyah, Y. (2021). The Influence of Corporate Ethics Culture on Whistleblowing Mechanisms and Their Impact on Fraud Detection (Empirical Study in the Anti Fraud Division of PT. Bank XYZ in Jakarta 2020). Asian Journal of Social Science Studies, 6(3), 1. https://doi.org/10.20849/ajsss.v6i3.932.

[40] Pamungkas, I. D., Wahyudi, S., \& Achmad, T. (2020). Whistljeblowing system and fraud early warning system on village fund fraud: The Indonesian experience. International Journal of Financial Research, 5(2), 151-158. https://doi.org/10.5430/ijfr.v10n6p211. 